\title{
Electrical Energy Access: A Viable Alternative for the Alleviation of the Nigerian Economy
}

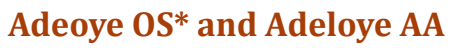 \\ Department of Electrical and Electronic Engineering, The Federal Polytechnic, Nigeria
}

*Corresponding author: Adeoye OS, Department of Electrical and Electronic Engineering, The Federal Polytechnic, Ado-Ekiti, Ekiti State, Nigeria, Email: adeoyesamuel2012@gmail.com

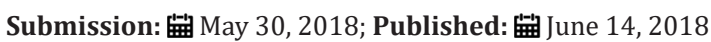

\begin{abstract}
Every sector of life, since the beginning of creation, has been impacted upon by one form of energy. The resultant effect varies globally depending primarily on the output desired. Electrical energy access and consumption in Nigeria was critically examined in this manuscript. The prevailing access status was identified and compared with existing consumption indices in other parts of the world. Consequently, the per capita demand for Nigeria was computed from its subsisting load requirement and population size. A significant disparity was observed upon comparison of the power generated and the load demand within the Nigerian nation. Similarly, specific values of the same parameters were obtained for different countries across the world and compared with the values obtained for Nigeria. Insufficient power supply and access was identified as a defect to national growth and development while a direct proportionality between the growth in electrical energy access and national economy was discovered. The factors of production were analysed with a view to proffer solution to the state of economy. Energy mix was proposed as an option that would alleviate the present economic status of Nigeria.
\end{abstract}

Keywords: Energy access; Energy mix; Load demand; Per capita demand; Economy

\section{Introduction}

Energy is defined as the ability to do work or the capacity of a system to perform a work. It can neither be created nor destroyed. However, it can be transformed from one form to another and its unit of measurement is Joules. Different forms of energy include light, chemical, heat, sound, nuclear, mechanical and electrical [1]. Every sector of life requires energy. In agriculture, it is used for pumping water for irrigation and methods of production. Electrical energy is superior to all other forms due to cheapness, convenient and efficient transmission, easy control, cleanliness, greater flexibility, versatile form [2]. The growing population of Nigeria is put at over 180 million while the power generation increased from less than $3000 \mathrm{MW}$ to $4000 \mathrm{MW}$ by September, 2016 [3,4]. This is paltry energy access for a sovereign federation with a total land mass of $923,768 \mathrm{~km}^{2}[5]$.

\section{Literature Review}

\section{Factors of production}

This is the means or agent of production. It is made up of the tangible and intangible resources that are combined together for production of goods and services. The factors are land, labour, capital and entrepreneurship.

Land: Land in economics refers to free gift of nature which Nigeria has in abundance. It's inclusive of natural resources such as water, sunshine, weather, forest, mineral deposits, animals, hills and fishing ground. Each of the items mentioned under this factor of production exists in abundance in the Nigeria and should be properly harnessed for growth and development.

Labour: This may be defined as all human efforts both physically and mentally that are directed towards production. It could also be described as the varieties of natural talents available within the society. This is a great weapon for development in Nigeria. Nigeria has a population of over 170 million. Skilled labour such as economist, engineers, lawyers, accountants, doctor among others, requires special skills and training. Semi skilled labour deals with acquisition of some training or skills due to constant exposure eg: clerical staff, auxiliary nurses, laboratory attendants. Unskilled Labour has no formal training eg: messengers, cleaners and guards.

Capital: Is the stock of previous wealth invested in order to obtain future wealth. It could be fixed capital such as machineries, buildings, motor vehicles, furniture etc. Working or circulating capital is inclusive of examples such as raw materials and cash in hand while current capital is required for day to day running of a firm or production activities. Also, there is a third subcategory called real capital which encompasses illustrations such as road, electricity (electrical energy) and water.

Entrepreneur: Can be defined as the factor of production that bears the risk of business activities. An entrepreneur controls and 
manages the business. In summary, the success or failure of the business depends on his or her ability to put things in the right perspective.

\section{Energy resources in Nigeria}

It is the continent's most prolific oil-producing country, which, along with Libya, accounts for two-thirds of Africa's crude oil reserves. It ranks second to Algeria in natural gas [6]. Most of Africa's bitumen and lignite reserves are found in Nigeria. Several energy resources are available in Nigeria in abundant proportions. The country possesses the world's sixth largest reserve of crude oil. Nigeria has an estimated oil reserve of 36.2 billion barrels. It is increasingly an important gas province with proven reserves of nearly 5,000 billion $\mathrm{m}^{3}$. Coal and lignite reserves are estimated to be 2.7 billion tons, while tar sand reserves represent 31 billion barrels of oil equivalent. The identified hydroelectricity sites have an estimated capacity of about 14,250MW.

Nigeria has significant biomass resources to meet both traditional and modern energy uses, including electricity generation [7]. In spite of these resources, an obvious supply and demand gap subsists as a result of the inadequate development and inefficient management of the energy sector. The supply of electricity, the country's most used energy resource, has been inconsistent $[8,9]$.

With the restructuring of the power sector and the imminent privatization of the electricity industry, the rural areas that are farther from the grid and/or have low consumption. Meanwhile, electricity is required for such basic developmental services as pipe borne water, health care, telecommunications, and quality education. The absence of reliable energy supply has not only left the rural populace socially backward, but has also left their economic potentials untapped. Energy consumption patterns in the world today shows that Nigeria and indeed African countries have the lowest rates of consumption. Nevertheless, Nigeria suffers from an inadequate supply of usable energy due to the rapidly increasing demand, which is typical of a developing economy. Paradoxically, the country is potentially endowed with sustainable energy resources such as solar, wind, biomass, and small hydropower potentials [10].
Nigeria is rich in conventional energy resources, which include oil, national gas, lignite, and coal. It is also well endowed with renewable energy sources such as wood, solar, hydropower, and wind [8].

\section{Per capita energy consumption in Nigeria}

The energy consumption per capita in Nigeria is very small about one-sixth of the energy consumed in developed countries. This is directly linked to the level of poverty in the country. Gross domestic product (GDP) and per capita income are indices that are used to measure the economic well-being of a country and its people [11]. GDP is defined as the total market value of all final goods and services produced within a given country in a given period of time (usually a calendar year). The per capita income refers to how much each individual receives, in monetary terms, of the yearly income that is generated in his/her country through productive activities. That is what each citizen would receive if the yearly income generated by a country from its productive activities were divided equally between everyone. At present, the Generation Companies (GENCOs) of the Nigerian electricity utility accounts for about $50 \%$ of the total generation [10]. Electricity is largely dependent on fuel such as fuel oil, natural gas, and diesel oil. These sources of energy have decreased significantly in recent years [11]. Comparing the per capita power generation to that of other countries, Nigeria has the lowest among the countries, as shown in Table 1, while the USA has the highest per capita electricity generation.

The estimated per capita demand for the entire country was computed using Equation 1. A value of $22.22 \mathrm{~kW}$ per capita was obtained. In spite of the increase in the Nigerian power generation from less than 2000MW to 4000MW within September, 2016

$$
\begin{gathered}
\text { PCD }=\frac{\text { Power supply to a specified area }}{\text { Population of the area }} \\
\qquad=\frac{4000 * 10^{6}}{180 * 10^{6}} \\
=22.22 \mathrm{kw} \text { per capita }
\end{gathered}
$$

\section{Energy consumption}

Table 1: Country statistics of electricity generation and per capita consumption.

\begin{tabular}{|c|c|c|c|c|}
\hline Continent & Country & Population (Million) & Generation Capacity (Mw) & Per Capita Consumption (Kw) \\
\hline North America & USA & 250 & 813,000 & 3.2 \\
\hline South America & Cuba & 10.54 & 4,000 & 0.38 \\
\hline Europe (Central) & UK & 57.5 & 76,000 & 1.1 \\
\hline Europe (Eastern) & Ukraine & 49 & 54,000 & 0.42 \\
\hline Middle East & Iraq & 23.6 & 10,000 & 1.1 \\
\hline Far East & South Korea & 47 & 52,000 & 1.33 \\
\hline
\end{tabular}




\begin{tabular}{|c|c|c|c|c|}
\hline \multirow{3}{*}{ Africa } & Nigeria & 140 & $<4,000$ & 0.03 \\
\cline { 2 - 5 } & Egypt & 67.9 & 18,000 & 0.27 \\
\cline { 2 - 5 } & South Africa & 44.3 & 45,000 & 1.02 \\
\hline
\end{tabular}

Source: IEA Energy statistics [9].

Table 2: Electric power consumption in developing and developed countries.

\begin{tabular}{|c|c|c|}
\hline $\mathrm{S} / \mathrm{N}$ & Countries & $\begin{array}{c}\text { Power Consumption } \\
(\mathrm{kWh})\end{array}$ \\
\hline 1 & Algeria & 133 \\
\hline 2 & Angola & 86 \\
\hline 3 & Argentina & 871 \\
\hline 4 & Bangladesh & 11 \\
\hline 5 & Bolivia & 165 \\
\hline 6 & Canada & 9301 \\
\hline 7 & Denmark & 3059 \\
\hline 8 & Ethiopia & 19 \\
\hline 9 & France & 2746 \\
\hline 10 & Germany & 4064 \\
\hline 11 & Iceland & 7002 \\
\hline 12 & Libya & 180 \\
\hline 13 & Mozambique & 50 \\
\hline 14 & Nepal & 6 \\
\hline 15 & Nigeria & 22 \\
\hline 16 & Switzerland & 4615 \\
\hline 17 & Tanzania & 30 \\
\hline 18 & Togo & 64 \\
\hline 19 & United Arab Emirate & 687 \\
\hline 20 & United Kingdom & 4255 \\
\hline 21 & United States of America & 7517 \\
\hline
\end{tabular}

Source: World bank data indicator [14].

The value of this parameter ranks highest among developed countries as illustrated in Tables 1 \& 2. America is less than $5 \%$ of the world's population and yet consumes as much as $25 \%$ of its energy. Energy consumption means consumption of the sources of energy that generate power including fossil fuels, and renewable energy. The main fossil fuels are oil, coal, and natural gas while the renewable energy sources include wind, solar, hydro electric power and bio-fuels. The world's energy consumption is about 15 Tera watts of power [12].

\section{Energy challenge}

The consumption of energy globally has increased steadily over the last 40 years with dramatic growth rates in many developing countries as described in Table 3. Even though there is imbalance in access to modern energy services. From 1970 to 1988, the developing countries' share of global primary energy consumption rose from $13 \%$ to about $30 \%$. In 2005, the non- OECD accounted for
$52 \%$ of global primary energy consumption. The average per capita consumption of energy in the OECD countries was more than four times the per capita average in all non OECD countries and nearly seven times the per capita average in Africa [13]. At least a quarter of the world's population of 6.6 billion people are unable to take advantage of basic amenities and opportunities made possible by modern forms of energy [9].

Table 3: Nigeria economy data.

\begin{tabular}{|c|c|c|c|c|c|}
\hline Years & $\mathbf{2 0 1 1}$ & $\mathbf{2 0 1 2}$ & $\mathbf{2 0 1 3}$ & $\mathbf{2 0 1 4}$ & $\mathbf{2 0 1 5}$ \\
\hline Population million & 160 & 165 & 169 & 174 & 179 \\
\hline GDP (\%) & 4.9 & 4.3 & 5.4 & 6.3 & 2.7 \\
\hline GDP(USD bn) & 418 & 446 & 498 & 553 & 479 \\
\hline
\end{tabular}

Source: Wikipedia [3].

The price of oil was US\$ 20 per barrel in 1999 and rose to US\$ 126 per barrel in 2008. The International Energy Agencies (IEA) projected that oil price will considerably drop in the next 20 years [13]. Per capital commercial energy demand is ten times greater in the richest developing countries such as Uruguay and Israel where less than $5 \%$ of the population is classified as poor than in the poorest countries such as Nigeria ad India where more than $75 \%$ of the population lives on less than $\$ 2$ a day. Table 4 depicts exchange rate of the Nigerian Currency to the American Dollar with a sharp $100 \%$ increase within 3 years [2012-2015].

Table 4: Exchange rate of Nigeria currency to American's dollar

\begin{tabular}{|c|c|c|}
\hline 2012 & 1 USD & $155.05-165$ NGN \\
\hline 2013 & 1 USD & $153.21-162.9$ NGN \\
\hline 2014 & 1 USD & $160-165$ NGN \\
\hline 2015 & 1 USD & 304.96 \\
\hline
\end{tabular}

Source: World bank [15].

\section{Energy access and economic growth}

Energy access, as an important economic factor, is not solely sufficient for creating the conditions for economic growth [14,15]. However, it is certainly very necessary. Economic growth almost always requires energy access especially in the tertiary stage of economic development. Access to energy contributed in no small measure to the economic growth in countries such as Brazil, Turkey, and Korea. Its impact was milder in India and China [16].

The significant difference in average indicators of social and economic conditions between developing and industrialized countries are briefly expressed as follows

Social: the citizens of OECD countries have a larger life expectancy of 76 years compared with an average 64 years in 
developing countries [17]. This is due to largely lower infant mortality rate of $9 / 1000$ live births compared to 71 developing countries.

Economic: average per-capital incomes are more than 8 times higher in OECD countries than in the developing countries.
Energy Development index is made up of the per capita commercial energy consumption, share of commercial energy in total fuel energy being utilized and the share of population with access to electricity. This parameter is depicted by Equation 2 [18] (Table 5).

Table 5: Contribution of factors of production and productivity of GDP growth, 1980-2001.

\begin{tabular}{|c|c|c|c|c|c|}
\hline Countries & Average Annual Growth GDP & Energy & Labour & Capital & Productivity \\
\hline Brazil & 2.4 & 77 & 20 & 11 & -8 \\
\hline China & 9.6 & 13 & 7 & 26 & 54 \\
\hline India & 5.6 & 15 & 22 & 19 & 43 \\
\hline Indonesia & 5.1 & 19 & 34 & 12 & 35 \\
\hline Korea & 7.2 & 50 & 11 & 16 & 23 \\
\hline Mexico & 2.2 & 30 & 60 & 6 & 4 \\
\hline Turkey & 3.7 & 71 & 17 & 15 & -3 \\
\hline United States & 3.2 & 11 & 24 & 18 & 4 \\
\hline
\end{tabular}

Source: IEA analysis based on IEA databases and World Bank [9].

$$
\text { Dimension Index }=\frac{(\text { Actual value }- \text { Minimum value })}{(\text { Maximum value }- \text { Minimum value })}
$$

\section{Methodology}

Information was obtained from reputable journals regarding the level of consumption of electrical energy in different parts of the world. Energy resources available in Nigeria were identified and

\section{Discussion}

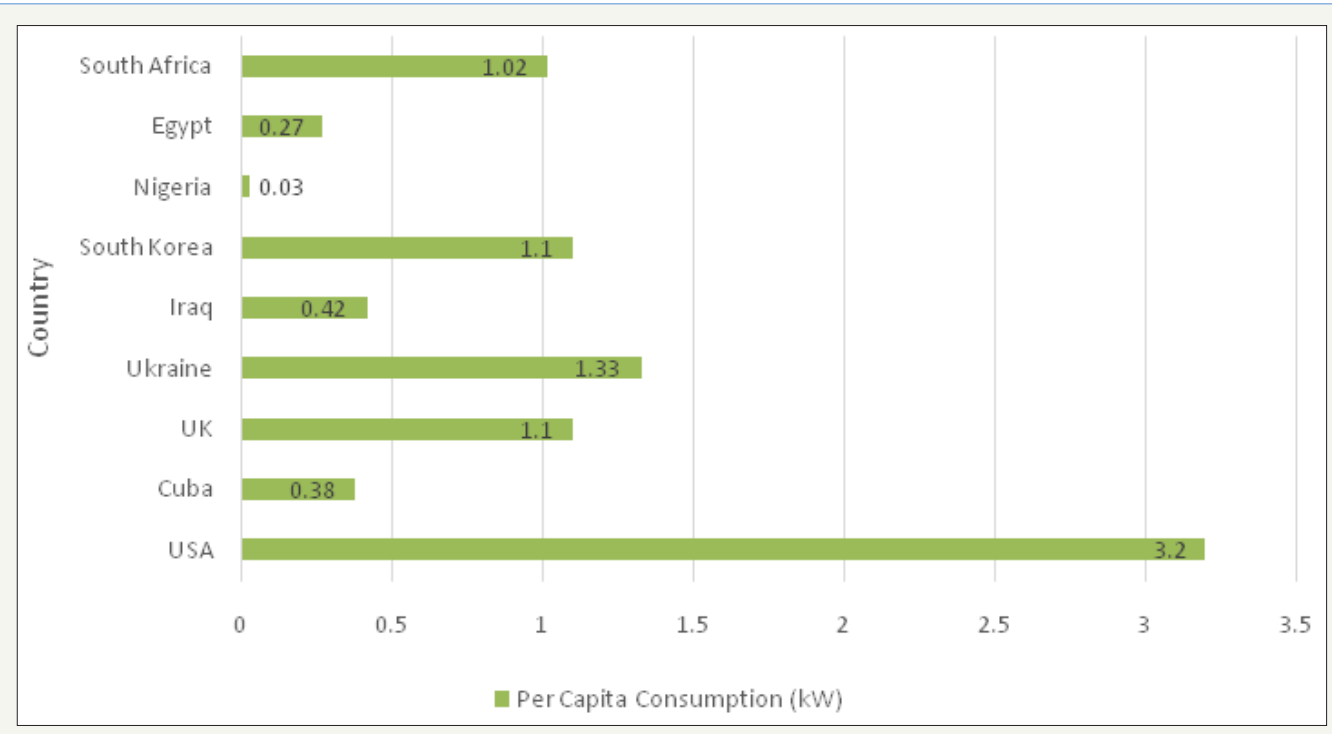

Figure 1: Bar chart of per capita energy consumption in various countries of the world.

Source: A review of latin america and africa [17].

The present per capita (PPC) computation of Nigeria from equation 1 is $22.22 \mathrm{~kW}$. This is better than the value of 0.03 it had in 2016 as displayed in Table 1 \& Figure 1, where Nigeria had the least per capita value among the group of nations under consideration. The present PPC value is far less than what is obtainable in the capacities of each were discussed [19]. The per capita demand for Nigeria was computed from its subsisting load requirement and population size while the value obtained was compared to that of selected countries in the world. The level of access of Nigerians to electricity was assessed and other factors of production were appraised in order to improve the present economic status of the nation. The sudden drop in the cost of crude oil per barrel was discussed as it affects the economy of the country. 
$\$ 135$ few years ago. It is no longer news that the price of Premium Motor Spirit (PMS) is $\$ 145$ which has affected the cost of living in the country [20]. Prices of commodities have sky rocketed and have become unaffordable for citizens. The exchange rate of a dollar to naira is $\mathrm{N} 360$. Since the economy of the country is import driven, cost of imported goods have increased and unaffordable by the citizens. The country should focus on energy mix by investing on renewable energy which will give room for close to $100 \%$ access to electricity in both rural and urban centres of the country. The use of generators as an alternative power source to homes and industries should be discouraged in order to minimize the amount of carbon mono oxide in the atmosphere which is poisonous to human health [21]. Agricultural sector must be revolutionised by using modern techniques whose bedrock is electrical energy. Refineries in existence should be revamped and new ones should be built to increase the capacity. Corruption campaign of this government should continue until our society is free from this menace.

\section{Conclusion}

The estimated $22.22 \mathrm{~kW}$ per capita demand depicts about $5 \%$ access to electrical energy in Nigeria. The incorporation of energy mix through renewable energy in every part of Nigeria will provide close to $100 \%$ access to electricity in the country. This will drive other sectors of the economy and life will be better.

\section{Recommendation}

1) Electricity access to every citizen of Nigeria at all year round will improve productivity and by extension, the economy of the Nigerian nation.

2) Renewable energy through energy mix will reduce incidences of power outage and invariably provide an improved living standard for Nigerians.

3) Agricultural revolution through the inclusion of modern mechanized techniques based on energy access will boost the economy.

4) Building of more refineries in the country will positively impact the naira to the dollar exchange rate, thereby reducing the rate at which Premium Motor Spirit (PMS) and other hydrocarbon derivatives are produced thereby, diminishing the fiscal recession of the Nigerian economic status.

5) The three tiers of government should put in place enabling environment for investors.

\section{References}

1. Nneji G, Okon E, Nwachukwu E (2008) NEEDC basic technology for junior secondary schools. Learn Africa Publishers, Nigeria, pp. 1-14

2. Gupta J (2006) A course in power systems. In: Katariia SK and Sons Publishers, New Delhi, India.

3. (2016) Wikipedia.

4. Adaba 88.9 FM (2016) News at five. Adaba Broadcasting Station, Akure, Ondo State, Nigeria.

5. http://www.tradingeconomics.com

6. (2016) USDA agricultural projections up to 2022.

7. http://www.investopedia.com

8. Adeoye O, Bamisaye A, Akinsanya O (2011) Renewable energy sources for socio economic growth and stability in Nigeria (Power demand and supply as a planning scheme). $7^{\text {th }}$ Engineering Forum, pp. 199-204.

9. (2004) IEA databases and world bank.

10. (2007)IEA energy statistics.

11. Adeoye OS (2014) Estimation of potential load demand of local government areas of Ekiti state, Nigeria. American Journal of Engineering Research 3(6): 101-106.

12. Adeoye OS, Akinsanya OA (2013) Estimation of power demand capacity for socio economic development in Nigeria. SEEM Research and Development Journal, pp. 19-30.

13. Adeoye 0, Titiloye S (2014) Erratic power supply and socio economic development in Ado-Ekiti, Ekiti State, Nigeria. The International Journal of Engineering and Science 3(6): 57-60.

14. (2016) World bank data indicator.

15. (2016) Worldbank.

16. Andy C (2001) Essential economics for secondary schools, Ikeja. Tonad Publishers Limited, Lagos, Nigeria.

17. Federico MB, Paula C, Rajendra SA, Angelo F (2016) Urban development and energy access in informal settlements: A review of Latin America and Africa. Procedia Engineering 161: 2093-2099.

18. Schnitzer D, Lounsbury S, Carvallo J, Deshmukh R, Apt X et al. (2014) Microgrids for rural electrification. United Nations Foundation, USA, pp. $1-120$.

19. Mimmi L (2014) From informal to authorized electricity service in urban slums: Findings from a household survey in Mumbai. Energy for Sustainiable Development 21: 66-80.

20. Butera F, Adhikari R, Caputo P, Facchini A (2015) The challenge of energy in informal settlements: A review of the literature for Latin America and Africa. Analysis of Energy Consumption and Energy Efficiency in Informal Settlements of Developing Countries, pp.1-32.

21. Depuru S, Wang L, Devabhaktunis V (2010) Electricity theft: Overview, issues, prevention and smart meter based approach to energy theft. Energy Policy 39(2): 1007-1015.
Creative Commons Attribution 4.0 International License

For possible submissions Click Here

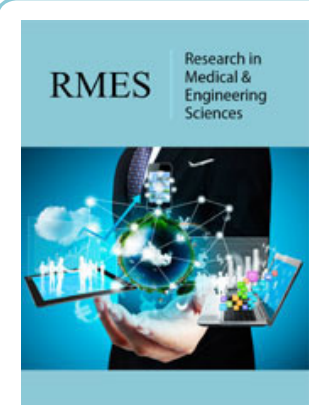

\section{Research in Medical \& Engineering Sciences}

\section{Benefits of Publishing with us}

- High-level peer review and editorial services

- Freely accessible online immediately upon publication

- Authors retain the copyright to their work

- Licensing it under a Creative Commons license

- Visibility through different online platforms 